\title{
Does Mandatory Audit Partner Rotation Influence Auditor Selection Strategies?
}

\author{
Li-Jen He and Jianxiong Chen *
}

check for

updates

Citation: He, L.-J.; Chen, J. Does Mandatory Audit Partner Rotation Influence Auditor Selection

Strategies? Sustainability 2021, 13, 2058. https://doi.org/10.3390/ su13042058

Academic Editor: Ionel Bostan

Received: 23 January 2021

Accepted: 10 February 2021

Published: 14 February 2021

Publisher's Note: MDPI stays neutral with regard to jurisdictional claims in published maps and institutional affiliations.

Copyright: (c) 2021 by the authors. Licensee MDPI, Basel, Switzerland. This article is an open access article distributed under the terms and conditions of the Creative Commons Attribution (CC BY) license (https:// creativecommons.org/licenses/by/ $4.0 /)$.
Department of Accounting, National Yunlin University of Science and Technology, Yunlin 64002, Taiwan; lijenho@yuntech.edu.tw

* Correspondence: d10825001@gemail.yuntech.edu.tw

\begin{abstract}
Under mandatory rotation, the switching cost may be the most influential factor to be considered for experienced mandatory audit rotations. This study attempts to explore the impacts of the mandatory rotation mechanism on company information disclosure and signaling strategies by examining the audit partner and audit firm switching activities of the mandatory rotation company. Are companies that experience mandatory audit rotation more likely to engage industry specialist auditors with better industry-specific knowledge and reputations to minimize the costs of mandatory rotations? Furthermore, in the case of being required to rotate audit partners, do companies rotate only audit partners, rather than changing both audit partners and audit firms at the same time, to minimize switching costs? To explore these problems, this study examined auditor rotations of listed companies in Taiwan from 2004 to 2016; and expected that, to minimize switching costs, mandatory rotation companies are more likely to select industry specialist auditors to be their successor auditors, and are less likely to rotate audit partners and audit firms at the same time. For the audit partner rotations, we find that, compared to voluntarily rotated companies, a higher percentage of companies choose industry specialist auditors to be their successor audit partners under mandatory rotation. Furthermore, the empirical results support our expectations that companies that experience mandatory audit partner rotation are significantly more likely to engage industry specialists to be their successor audit partners and are more likely to rotate only audit partners rather than rotating both audit partners and audit firms around mandatory audit rotation periods.
\end{abstract}

Keywords: mandatory audit rotation; auditor selection strategies; audit partner; audit firms

\section{Introduction}

Prior studies suggested that sustainable development is closely related to economic efficiency, energy consumption, and many other factors [1,2]. In terms of audit sustainability, Chen et al. [3] and Sun et al. [4] pointed out that companies' auditor selections are related to their sustainability-related activities, and the selection of different auditors may have significant impacts on the sustainable management and market reaction of enterprises. For instance, Chen et al. [3] indicated that firms can signal their commitment to providing reliable corporate social responsibility (CSR) information through their expenditure in auditing, which implies their commitment to high quality financial reporting. Accordingly, the rotation mechanism of auditors should be associated with the company's sustainability related activities as well. Moreover, Sun et al. [4] found that the engagement of industry specialist auditors is associated with higher CSR ratings of companies, while the environment in controversial industries are found to select non-specialized auditors. Therefore, the objective of this study is to explore the influence of mandatory audit partner rotation mechanism on companies' auditor selection strategies.

The impacts of mandatory audit rotation have been a long-standing debate in academic research and practice. However, while prior studies have extensively discussed the influence of mandatory audit rotation, rarely have they explored the company's response to this provision. Under mandatory rotation, it was known ahead of time when a change 
was scheduled, and incoming auditors following mandated changes also knew that their tenure was limited to a maximum period specified by the rotation regime rules [5]. Under this circumstance, companies may have had different auditor selection strategies between mandatory and voluntary rotations. Since mandatory audit rotation is considered one of the most important mechanisms to strengthen auditor independence and improve audit quality, the cost and efficiency of mandatory rotation are still controversial. Moreover, because mandatory rotation is more likely to improve audit quality when the incoming auditor is well-informed about the new client, knowledge about the new client of successor auditors should be considered when discussing the influences of mandatory auditor rotation.

For auditor choice decisions, Tanyi et al. [5] recognized that voluntarily and mandatory rotating of auditors are quite different. For instance, voluntary rotation by a company may be undertaken for seeking audit-fee savings or better services [6,7], but employing mandatory rotation is undertaken only because it is required. Moreover, although companies that voluntarily and mandatorily switch their auditors experience consequences of the selections of successor auditors, companies that mandatorily rotate should rely more on the auditors they switch to because they continuously engage the auditors until they are rotated.

From the perspective of reporting strategy, Copley and Douthett [8] suggested that selecting an auditor, which can be seen as a signal of audit quality, may be one process that minimizes the overall cost of signaling (Copley and Douthett [8] used the USA IPO sample going to the market between 1990 and 1997 to investigate the association between auditor choice, retained ownership, and earnings disclosure, and suggested that these signals are jointly determined). Sun et al. [4] suggested that a commitment to higher financial reporting quality has the potential to bring positive externality to firms, nonfinancial disclosures and ultimately affects the issuance of CSR reports. In terms of auditor selection, will companies that have experienced mandatorily audit partner rotations be more likely to choose industry specialist auditors to signal their willing of committing to higher financial reporting quality which implies higher investment in sustainability? To explore this question, this study examines the effects of the successor auditor choice for mandatory auditor rotation companies.

This study takes the audit partner rotation data of Taiwan listed companies from 2004 to 2016 as a sample to test the hypotheses. Taiwan's regulations require audit partner rotation, which will allow us to examine the selection of successors at the audit partner level for companies with mandatory rotation. We expect that there will be differences in the consideration and selection of successor auditors between voluntary and mandatory rotation firms. In addition, the choice of a specialist auditor with better knowledge of a specific industry may enhance the credibility of financial statements and indicate a willingness to commit to higher quality financial reporting, thus enabling the firm to reduce the cost of mandatory rotation. As a result, we expect companies with mandatory rotation to be more likely to hire industry specialists as successor auditors than those with voluntary rotation. From the perspective of the auditor-client relationship, mandatory rotation should be less costly if it is only rotated at the partner level, not at the firm level. Therefore, we expect that client firms are more likely to rotate only audit partners for mandatory rotation than firms that rotate both audit firms and partners.

The empirical results show that there are differences in successor auditor selection between firms with mandatory audit partner rotation and those with voluntary audit partner rotation, and firms with mandatory audit partner rotation are more likely to hire industry specialists as their successors audit partners in order to minimize auditor switching costs. In addition, the empirical results show that compared with voluntary rotation firms, mandatory rotation firms are more likely to rotate only audit partners, rather than both audit partners and audit firms. However, additional tests show that mandatory rotation has a significant impact on the selection of industry specialist successor audit partners for firms that mandatorily rotated only one of two partners. 
Previous studies mainly focused on audit quality after mandatory rotation, while this study is expected to fill the gap in existing audit literature by discussing mandatory rotation issues on selection of successor auditors. Additionally, the empirical results of current study provide evidence related to the reactions of client companies to mandatory audit rotation and responses to the consideration of that to use "auditee" as a research object has remained virtually ignored in the literature. Finally, the results of this study provide an empirical basis for the continuous debate between the practitioners and regulators on the issue of mandatory rotation from different perspectives.

The rest of this article is organized as follows. In the second section, we will introduce the institutional background, review the relevant literature, and discuss our main hypotheses. The third section describes the study design, sample selection process, and data source. The fourth section gives the empirical results, and the final section discusses the research findings.

\section{Institutional Background, Literature Review, and Hypotheses}

\subsection{Institutional Background}

In practice, mandatory audit rotation is a frequently discussed issue among regulatory bodies in worldwide, especially after the global financial crisis; however, the requirement of auditor rotation remains a subject of debate. In the United States, mandatory rotation was reconsidered following the accounting scandals at Enron Corp. and WorldCom Inc. that ultimately led to the passage of the Sarbanes-Oxley Act in 2002 (SEC Practice Section of AICPA required audit partners of public companies be rotated at least once every 7 years, and Section 203 of the Sarbanes-Oxley Act (SOX) codified a partner tenure limitation for public companies into law and reduced the period to 5 years). Similarly, many other countries also began requiring some form of audit partner rotation and cooling off. For instance, in 2011, the European Commission proposed mandatory audit firm rotation every 6 years with a 4-year cooling-off period. However, after 10 years, debates continued on the effects of mandatory rotation on audit practice, and the U.S. House of Representatives blocked the mandatory rotations of auditors in July 2013.

To enhance auditor independence, since 2003, listed companies in Taiwan are required to rotate their audit partner every 5 years or undergo a "substantive review" by the Taiwan Stock Exchange Corporation (TWSE) and Gre-Tai Securities Market (GTSM). Under this requirement, listed companies are substantially reviewed if any one of their lead or concurring partners provide audit services for more than 5 continuous years. If any significant violation of accounting or auditing standards is found, punishment may include reprimand, suspension of license, or even criminal charges. Consequently, to avoid the trouble or potential punishments from a substantial review, listed companies and audit partners rotate every 5 years.

Additionally, Article 47 of the Certified Public Accountant Act states that certified public accoutants (CPAs) who fail to comply with the governing CPA rotation may not be contract to perform attestation on financial reports. Therefore, the rotation of audit partners every 5 years in Taiwan is a matter of fact. Using this unique setting, we are able to discuss the successor auditor choice for mandatory audit rotation companies at the partner level. The length of continuous audit year was extended to be 7 years from 2009.

\subsection{Literature Review and Hypotheses Development}

\subsubsection{Auditor Selection Strategies}

Auditor selection is one of the most important considerations of a company's information disclosure strategy, and has been demonstrated to be associated with a company's aims of signaling [9-16], earnings management [17-20], opinion shopping [19,21-25], advising $[9,26]$, and industry competition [27].

Since the switch of an auditor is required, some intensions are less likely to be present under mandatory rotation. Nagy [28] demonstrated that a company, since it is required (mandatorily) and desires (voluntarily) to switch auditors, may act differently for the reason 
that companies that make a voluntary auditor switch can look for auditors that are more favorable to them. Scott and Gist [29] discussed the impact of industry specialization on audit absorption and competitive pricing of large Andersen clients (S\&P 1500 companies), who turned to the Big 4 audit firms due to the demise of Arthur Andersen LLP(Chicago, IL, USA) (Andersen) in 2002, and found that for companies wishing to signal audit and financial reporting quality to influence market perception, a mandatory audit company rotation will have a high cost impact on the pricing of the Big 4 audits, and large companies may lose their ability to bargain for lower audit fees.

In addition, researchers from different industries have explored the relationship between costs and the actual situation of industries [30]. Under mandatory audit firm rotation, Blouin et al. [31] and Chen et al. [32] believed that companies with higher switching costs were more likely to follow their former auditors, while companies with greater concerns about an agency were more likely to sever ties with former auditors. Ettredge et al. [6] also proved that the total switching cost is one of the main factors considered in the companies' auditor switch decisions. Moreover, Copley and Douthett [8] believed that the signals selected are measured through the retained ownership, as well as auditor selection and disclosure in their research, which are correlated through their cost structures, and are collectively selected to minimize the overall cost to entrepreneurs.

The above research shows that the costs of mandatory rotation play the most important role in hiring subsequent auditors, and the results of audit firm rotation may not involve audit partner rotation. In conclusion, although voluntary rotation of companies may have specific reasons for rotating auditors, the consequences of selecting successor auditor should be the most important consideration in mandatory rotation of companies, as it is less likely to have specific intentions.

\subsubsection{Selection of Industry Specialist Auditors}

For the selection of a successor auditor under mandatory rotation, companies should try to find auditors to minimize rotation-related costs since the selection of the successor auditor is the most important factor affecting the consequences of mandatory rotation. Ruhnke and Schmidt [33] suggest that although mandatory audit firm rotations are expected to increase auditor independence and professional skepticism, this increase is offset by a decrease in other beneficial attributes, particularly client-specific expertise and knowledge.

From the perspective of reducing switching costs, Blouin et al. [31] believed that mandatory rotation companies would pursue successors who could reduce switching costs to the minimum and follow their former audit teams to serve clients and industry-specific knowledge (Blouin et al. [31], where switching cost is defined as the client in the new audit business start-up costs, including (1) costs incurred by client providing auditors with education on the daily operation of enterprises, financial systems, financial reporting practices, and existing accounting issues, (2) costs incurred by client in selecting new auditors for auditing, and (3) costs incurred by the increased risk of audit failure [34-38]. Under a mandatory partner rotation mechanism, costs about selecting a new auditor are not omissible; therefore, we discuss only two types of cost in this study). Under mandatory partner rotation, although according to regulations, companies are prohibited from following the original audit teams; they can switch to audit partners with better industry-specific knowledge to minimize switching costs. In addition, with regard to the increased risk of audit failure associated with switching auditors, industry specialist auditors with higher audit quality [39-44] can also help mandatory rotation firms to reduce the possibility of audit failure.

Moreover, from the signaling perspective, engaging an industry specialist auditor may also moderate agency costs and companies' commitment to providing reliable information [3] for mandatory auditor rotation companies, since industry specialists are expected to have higher audit quality $[15,39,42-46]$. Are companies that have experienced mandatorily audit rotation more likely to engage industry specialist auditors who have 
better industry-specific knowledge and reputations to minimize the costs of mandatory rotations? In order to explore this question, we develop the first hypothesis as follows:

Hypothesis 1. Compared to voluntarily rotation companies, mandatory rotation companies are more likely to engage industry specialists as successor auditors.

We expect that companies with mandatory auditor rotation will be more likely to hire industry specialist auditors with better industry knowledge and reputation to reduce the costs of mandatory auditor rotation compared to companies with voluntary auditor rotation.

\subsubsection{Rotated Levels}

In addition to choosing audit partners, mandatory rotation companies must also decide whether to follow the original audit firm. In terms of cost-effectiveness, the main benefit of auditor rotation is that compared with the longstanding auditor, the new auditor may be more independent and can look at the company's financial statements from a fresh perspective to improve the quality of the audit. Therefore, from the viewpoint of enhancing auditor independence, compared to rotating audit partners, mandatory rotation of audit firms should be more effective in cutting the relationships and economic bonds between auditors and their clients. However, changing the auditor may also reduce the quality $[45,47,48]$ of the audit because the new auditor does not understand the characteristics of the company or the industry as well, and fails to discover important matters to be audited in time.

According to prior studies, the auditor's knowledge of specific industries or clients can have a spillover effect in the same firm. From the viewpoint of retaining industry specialization, the cost of understanding a rotated-in client should be lower for mandatory audit rotation only at the partner level, not at the firm level, especially for their specialized industries.

In the case of being required to change the auditor, if the firm is changed at the same time, the cost of auditor rotation (the diminishing of audit quality caused by the successor auditor's less understanding of the industry or company) may be even higher. Moreover, for companies that rotated by the required time (rather than rotated earlier voluntarily), they are likely to have a good cooperative relationship and be familiar with the working mode of audits. Compared with different firms, the audit work mode will be more similar in the same firm. In this case, staying in the original firm can not only retain its benefits due to knowledge spillover, it can also save the cost of re-understanding each other due to the conversion of firms. Therefore, it should be more cost-effective to switch audit partners only rather than switch audit partners and audit firms both under mandatory audit rotation. In the case of being required to rotate audit partners, will companies that have rotated only audit partners, rather than changing both audit partner and audit firm at the same time, be able to minimize switching costs? In order to explore this question, we develop the second hypothesis as follows:

Hypothesis 2. Compared to voluntarily rotation companies, mandatorily rotation companies are more likely to switch only audit partners for mandatory rotation.

We expect that, to minimize switching costs, rather than changing both audit partner and audit firm, mandatory rotation companies are more likely to follow their former audit firm for their client and for industry-specific knowledge. 


\section{Research Design}

\subsection{Empirical Model}

To examine the hypotheses, this study first provides the following regression to test successor auditor choice strategies for mandatory and voluntary rotation companies:

$$
\begin{aligned}
\text { SUCCESSOR }= & \alpha_{1}+\beta_{1} \text { MANROT }+\beta_{2} \text { SIZE }+\beta_{3} \text { LEVERAGE }+\beta_{4} L O S S+\beta_{5} \text { CFO } \\
& +\beta_{6} \text { GROWTH }+\beta_{7} \text { ABSTACC }+\beta_{8} \text { INST }+\beta_{9} \text { BIGN }+\beta_{10} B O A R D \\
& +\beta_{11} \text { BHOLD }+\beta_{12} \text { BPLEDGE }+\beta_{13} \text { BIND }+\beta_{14} \text { BCONTROL }+\varepsilon
\end{aligned}
$$

where

SUCCESSOR = successor auditor choice of sample companies, which denotes 1 for the company that choose an industry specialist audit partner to be its successor auditor and 0 otherwise for Hypotheses 1; and 1 for companies that rotate audit firms around the rotation period, and 0 otherwise for Hypothesis 2;

$M A N R O T=$ an indicating variable of mandatory rotation, which denotes 1 if the company is mandated to rotate its audit partner this year, and 0 otherwise;

SIZE $=\log 10$ of total assets;

LEVERAGE = the amount of long-term debts divided by total assets;

LOSS = dummy variable that equals 1 if net income $<0$ for company $\mathrm{i}$ in industry $\mathrm{k}$ for year $\mathrm{t}$, and 0 otherwise;

$C F O=$ net cash flows from operations scaled by the beginning book value of total assets; $G R O W T H=$ the growth rate of net sales over the previous year;

$A B S T A C C=$ absolute value of total accruals scaled by total assets;

$I N S T=$ percentage of stock owned by institutional investors;

$B I G N$ = a dummy variable equal to1 if the company is audited by a Big $\mathrm{n}$ audit firm, and 0 otherwise;

$B O A R D=$ the board size, measured by the number of board of directors and supervisors; $B H O L D=$ the board share-holdings ratio, measured by the percentage of director and supervisor stockholdings;

$B P L E D G E$ = ratio of shares pledged, measured by the percentage of shares pledged by board members;

$B I N D=$ the number of independent directors and supervisors;

$B C O N T R O L=$ the number of controlled directors and supervisors.

The SUCCESSOR will be denoted 1 for the company that choose an industry specialist audit partner to be its successor auditor and 0 otherwise for Hypotheses 1; and 1 for companies that rotate audit firms around the rotation period for Hypothesis 2 and 0 otherwise. The main variable of interest is MANROT, which represents successor audit partner selection for mandatory audit partner rotation firms. MANROT is an indicative variable for mandatory audit rotation and is used to explore the relationship between mandatory audit partner rotation and successor auditor selection. In addition, to control for regression results, we consider variables that have been shown to influence the choice of a firm's auditor based on previous research. We also include the following variables that have been shown to influence the selection decisions of corporate auditors.

First of all, we include SIZE to control for the fact that compared to small companies, large companies are more likely to engage high-quality auditors. In addition, prior studies suggest that the risk level of companies may influence their demand for high quality auditors [49-52]. Therefore, we include a dummy variable for net loss (LOSS) to control for the influence of risk on choice of audit partners for sample companies. Leverage (LEVERAGE) is included to control for the probability that lenders require high-debt firms to engage high-quality auditors for monitoring purposes. We also include net cash flow (CFO) and total accruals (ABSTACC) to control the endogenously generated opportunities for earnings management because earnings management intentions have widely been suggested as related to companies' auditor selection decisions [17-20]. Furthermore, for the reason that board of directors have the voting right to influence auditor choice of 
companies, we include board size (BOARD), board share-holdings ratio $(B H O L D)$, ratio of shares pledged (BPLEDGE), the number of independent directors and supervisors $(B I N D)$, and the number of controlled directors and supervisors (BCONTROL) to control the influences of director board on companies' auditor choice.

\subsection{Measures of Industry Specialization}

According to prior studies [39,41,45,53-55], we will use an audit partner's or an audit firm's market share as a proxy for the audit partner's or audit firm's industry specialization. Furthermore, among definitions of market share, we will use their client's sales to measure the market share of audit firms (auditors) since it has been used most often in prior studies (Although most prior studies have used market share as a proxy for an audit firm's or auditor's specialization, they have based the use on different definitions of market share such as clients' sales, clients' assets, client numbers, audit fee and so on).

\subsubsection{Industry Specialist Audit Partner}

Since the audit reports of public companies in Taiwan must disclose the names of audit partners and audit firms, we can measure the specialization of both a specific audit firm and of an audit partner. We measure the specialization of an audit partner $(i)$ in a specific industry $(k)$ year as:

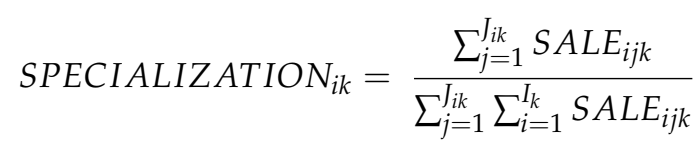

where SALE denotes clients' sales revenue, and the numerator is the sum of sales of all the audit partner i's clients $(j)$ in industry $k$. The denominator in Equation (1) is the total sales of industry $k$. Then, we identify the audit partners that have market share beyond 10 percent (In our main analyses, we use the largest market share to identify the industry specialist according to Chin and Chi [41] who explore the influence of auditor industry specialization of accounting restatement in Taiwan. Besides, since prior studies have used arbitrary market share percentages, such as $10 \%, 15 \%$, or $30 \%$, to denote auditor industry expertise [54,56,57], we will consider other proper cutoff point for the specialist distribution for sensitive analyses) in an industry as specialist audit partners and construct an indicator variable that equals one if the audit partner of a company is an industry specialist, and zero otherwise.

Moreover, while the requirement for dual signatures (In Taiwan, public companies are required to engage two audit partners to audit their financial reports and both auditors have to sign for the audit reports) in Taiwan raises a measurement issue concerning the identification of individual specialists, we believe that the specialist of any single audit partner can be shared with the entire audit team.

\subsubsection{Industry Specialists Audit Firm}

We use similar procedures to measure audit partner specialists in a specific industryyear to identify audit firm specialist. Equation (2) is revised so all i's denote audit firms, and we identify all audit firms with the largest market share of an industry as a specialist audit firm. Then, we construct an indicator variable that equals one if the audit firm is an industry specialist, and zero otherwise.

\subsection{Sample Selection}

The empirical data in this study will include auditor rotation companies in Taiwan between 2004 and 2016. All necessary data will be collected from the Taiwan Market Observation Post System and the Taiwan Economic Journal Database (TEJ). Then, we observe the auditor's changes in their information to check the reasons for the auditor's changes, in order to ensure that it is produced by mandatory rotations. Table 1 shows the sample selection and composition. We first got the total number of listed companies in Taiwan from 
2004 to 2016 from the TEJ. After that, we removed TDR companies and financial institutions because their corporate characteristics and audit requirements were very different from those of other industries. Next, we deleted observations that did not have sufficient auditor data or did not have the required financial data. Applying the above criteria, we obtained a total sample of 19,545 companies. Finally, we excluded firms that did not have rotate audit partners in certain years, and we got a total of 7789 rotated companies from 2004 to 2016. Panel B of Table 1 shows that the amount of companies that mandatorily rotated their audit partners is 1372 , and is about $17.61 \%$ of total companies that rotated their audit partners in our sample. In addition, the table shows that among companies rotating their audit partners, about $7.76 \%$ are rotated from industry specialist audit partners; which is slightly lower than the number that are rotated to industry specialist audit partners (about 8.09\%). In other words, while some companies switch between specialist audit partners, some companies switch from specialist audit partners to non-specialist ones. When examining the audit partner rotations for mandatory and voluntary further, we can see that, compared to voluntarily rotated companies, higher percentage of companies choose industry specialist auditors to be their successor audit partners under mandatory rotation. From the information presented in Table 1, we can see that the problems proposed by this study may exist; that is, the choices of auditors are different between mandatory and voluntary rotation companies; and compared to voluntary rotation companies, mandatory rotation companies have a higher rate of hiring industry specialists as their successor auditors.

Table 1. Sample selection and composition.

\begin{tabular}{|c|c|c|c|c|c|c|}
\hline \multicolumn{7}{|c|}{ Panel A: Sample Selection } \\
\hline \multicolumn{5}{|c|}{ Total companies on TWSE from 2004-2016 } & \multicolumn{2}{|c|}{20,052} \\
\hline \multicolumn{5}{|c|}{ Less: Companies without required financial data } & \multicolumn{2}{|c|}{$(204)$} \\
\hline \multicolumn{5}{|c|}{ Less: Companies without required other data } & \multicolumn{2}{|c|}{$(303)$} \\
\hline \multicolumn{5}{|c|}{ Sample companies with sufficient data } & \multicolumn{2}{|c|}{19,545} \\
\hline \multicolumn{5}{|c|}{ Less: Companies did not rotate audit partners } & \multicolumn{2}{|c|}{$(11,756)$} \\
\hline \multicolumn{5}{|c|}{ Total Companies of audit partner rotation data from 2004-2016 } & \multicolumn{2}{|c|}{7789} \\
\hline \multicolumn{7}{|c|}{ Panel B: Distribution of audit partners' rotations } \\
\hline & $\begin{array}{l}\text { Mandatory } \\
\text { Rotation }\end{array}$ & $\%$ & $\begin{array}{l}\text { Voluntary } \\
\text { Rotation }\end{array}$ & $\%$ & Total & $\%$ \\
\hline Companies & 1372 & 17.61 & 6417 & 82.39 & 7789 & 100.000 \\
\hline \multicolumn{7}{|l|}{ Rotated from } \\
\hline Specialist & 105 & 7.653 & 499 & 7.745 & 604 & 7.755 \\
\hline \multirow[t]{2}{*}{ Non-specialist } & 1267 & 92.345 & 5920 & 92.255 & 7185 & 92.245 \\
\hline & 1372 & 100.000 & 6417 & 100.000 & 7789 & 100.000 \\
\hline \multicolumn{7}{|l|}{ Switch to } \\
\hline Specialist & 113 & 8.236 & 517 & 8.057 & 630 & 8.088 \\
\hline \multirow[t]{2}{*}{ Non-specialist } & 1259 & 91.764 & 5900 & 91.943 & 7159 & 91.912 \\
\hline & 1372 & 100.000 & 6417 & 100.000 & 7789 & 100.000 \\
\hline
\end{tabular}

\section{Empirical Results}

\subsection{Descriptive Statistics}

Table 2 reports descriptive statistics for all the variables. For the mandatory audit partner rotation (MANROT) indicator variable, we can find that approximately $17.6 \%$ of the sample firms experienced mandatory auditor rotation from 2004 to 2016. For the indicator of choosing industry specialist to be the successor auditors, SUCSPE_F and SUCSPE_P indicate that, on average, about $1.7 \%$ and $8.1 \%$ companies choose industry specialist audit firms and industry specialist audit partners to be their successor, respectively. The control variables are generally comparable with those reported in previous studies. For the engagement of audit firms, the average of BIGN shows that more than $85 \%$ of sample companies are audited by Big $\mathrm{N}$ audit firms. In addition, the table displays that, on average, about $37.4 \%$ of sample companies' shares are owned by institutional investors (INST) while the percentage of director and supervisor stockholdings (BHOLD) is about $24.28 \%$. 
Correlations between the variables are presented in Table 3. From Table 3, we can find that, the indicator variable of mandatory audit partner rotation (MANROT) is significant positively associated with both SUCSPE_F and SUCSPE_P, which indicate that companies that experience mandatory audit partner rotations are significantly more likely to choose industrial specialist audit firms and specialist audit partners to be their successors.

\subsection{Mandatory Auditor Rotation and Successor Audit Partner Choice}

Table 4 shows the regression results of the association between mandatory audit partner rotation and successor audit partner selection. First, in order to examine the relationship between mandatory audit partner rotation and the firm's selection of successor audit partners for industry-specific auditors, two regressions were used to investigate the impact of mandatory audit partner rotation. The first regression, which is shown in Panel A of Table 4, used an indicating variable to denote the company that mandated to rotate any one of its audit partner (MROT1); and the second regression, which is shown in Panel B of Table 4, used an indicating variable to denote the company mandated to rotate both of its audit partners (MROT2). Panels A and B in Table 4 show that both MROT1 and MROT2 are significantly positively correlated with the engagement of industry specialist auditors. Therefore, firms that mandatorily rotated their audit partners are more likely to hire industry specialist as successors to their audit partners, regardless of whether they are mandated to rotate only one or two audit partners. These results support the first hypothesis that mandatory audit rotation firms are more likely to hire specialist auditors with high industry expertise and reputation to minimize the switching costs caused by required auditor rotation.

In addition to choosing audit partners, mandatory rotation firms must decide whether to follow the original audit firm. Therefore, we further investigate the relationship between mandatory audit partner rotation and the decision to switch audit firms. Panel C in Table 4 shows that MROT1 is significantly negatively correlated with changes of audit firms. Therefore, the result supports the second hypothesis, mandatory rotation firms are more likely than voluntary rotation firms to rotate only audit partners during the mandatory audit rotation period, rather than both audit partners and audit firms.

\subsection{Sub-Sample Regression Results}

While requiring listed companies with any one of their lead or concurring partners who provided audit services more than certain (The mandatory audit partner rotation that began in 2004 is to conduct a substantive examination if the norm is not rotated for five years. However, this length of the continuous audit year was extended to be 7 years after 2009. Consequently, this study used 5 years and 7 years to determine the rotation is mandatory or voluntary one before and after 2009 respectively.) continuous years to rotate their auditors, the TWSE and GTSM retain the flexibilities for companies that both lead and concurring partners provide audit services more than five continuous years to rotate only one of them for each year. However, it is possible that companies, to gain better market reactions or some other reasons, just decide to rotate both of their audit partners at the same time. Chi et al. [58] indicate that the effect of mandatory rotating both audit partners could differ from the effect of mandatory rotation only one of them. To address these considerations, this study process tests for companies that rotated only one audit partner and both lead and concurring partners, respectively. 
Table 2. Descriptive statistics.

\begin{tabular}{|c|c|c|c|c|c|c|c|c|}
\hline & $\mathbf{N}$ & Min. & $25 \%$ & Median & Mean & $75 \%$ & Max. & Std. Dev \\
\hline SUCSPE_F & 7789 & 0.000 & 0.000 & 0.000 & 0.017 & 0.000 & 1.000 & 0.130 \\
\hline SUCSPE_P & 7789 & 0.000 & 0.000 & 0.000 & 0.081 & 0.000 & 1.000 & 0.273 \\
\hline MANROT & 7789 & 0.000 & 0.000 & 0.000 & 0.176 & 0.000 & 1.000 & 0.381 \\
\hline SIZE & 7789 & 4.379 & 6.174 & 6.535 & 6.644 & 6.985 & 9.879 & 0.691 \\
\hline LEVERAGE & 7789 & 0.000 & 0.000 & 0.030 & 0.073 & 0.118 & 0.889 & 0.098 \\
\hline LOSS & 7789 & 0.000 & 0.000 & 0.000 & 0.215 & 0.000 & 1.000 & 0.411 \\
\hline $\mathrm{CFO}$ & 7789 & -5.451 & & 0.067 & 0.065 & 0.132 & 1.750 & 0.173 \\
\hline GROWTH & 7789 & -68.739 & & 4.951 & 9.636 & 19.454 & 232.877 & 37.579 \\
\hline INST & 7789 & 0.000 & & 34.320 & 37.395 & 53.950 & 100.000 & 22.844 \\
\hline BIGN & 7789 & 0.000 & & 1.000 & 0.852 & 1.000 & 1.000 & 0.355 \\
\hline BOARD & 7789 & 1.000 & & 9.000 & 9.508 & 10.000 & 32.000 & 2.494 \\
\hline BHOLD & 7789 & 0.000 & & 20.860 & 24.277 & 31.460 & 99.710 & 14.871 \\
\hline BPLEDGE & 7789 & 0.000 & & 0.000 & 8.035 & 7.165 & 99.970 & 16.916 \\
\hline BIND & 7789 & 0.000 & & 2.000 & 1.497 & 3.000 & 6.000 & 1.368 \\
\hline BCONTROL & 7789 & 0.000 & 3.000 & 4.000 & 4.977 & 6.000 & 25.000 & 2.570 \\
\hline
\end{tabular}

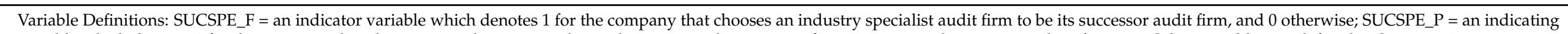
variable which denotes 1 for the company that chooses an industry specialist audit partner to be any one of its successor audit partner, and 0 otherwise; Other variables are defined in Section 3.1 . 
Table 3. Correlation matrix.

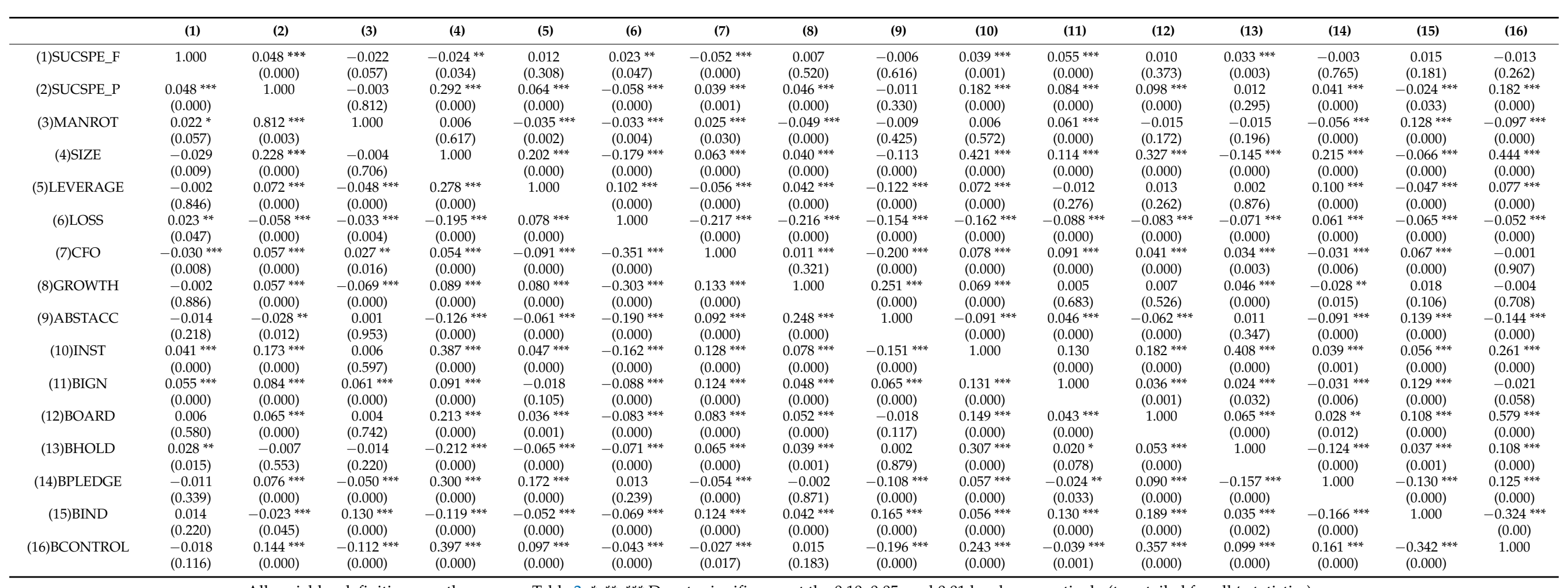

All variables definitions are the same as Table $2 .{ }^{*},{ }^{* *},{ }^{* * *}$ Denote significance at the $0.10,0.05$, and 0.01 levels, respectively (two-tailed for all $t$-statistics). 
Table 4. Full sample logistic regression results of mandatory audit partner rotation and the successor auditor choice.

\begin{tabular}{|c|c|c|c|c|c|c|}
\hline & \multicolumn{2}{|c|}{ Panel A } & \multicolumn{2}{|c|}{ Panel B } & \multicolumn{2}{|c|}{ Panel C } \\
\hline & \multicolumn{2}{|c|}{ SUCSPE } & \multicolumn{2}{|c|}{ SUCSPE } & \multicolumn{2}{|c|}{ CHANGEFIRM } \\
\hline & Coeff. & Wald & Coeff. & Wald & Coeff. & Wald \\
\hline MROT1 & $0.322 * *$ & 5.634 & & & $-0.773^{* * *}$ & 25.634 \\
\hline MROT2 & & & $0.727^{* *}$ & 5.630 & & \\
\hline SIZE & $1.497^{* * *}$ & 248.255 & $1.499^{* * *}$ & 248.576 & $-0.900 * * *$ & 79.190 \\
\hline LEVERAGE & -0.264 & 0.267 & -0.276 & 0.292 & $0.848^{*}$ & 3.483 \\
\hline LOSS & 0.033 & 0.054 & 0.022 & 0.026 & $0.508^{* * *}$ & 21.951 \\
\hline CFO & $0.557^{*}$ & 2.988 & $0.548^{*}$ & 2.899 & $-1.277^{* * *}$ & 27.847 \\
\hline GROWTH & $0.003^{* *}$ & 5.331 & $0.003^{* *}$ & 5.328 & 0.001 & 1.460 \\
\hline ABSTACC & $0.671^{* *}$ & 6.597 & $0.666^{* *}$ & 6.523 & $-0.681^{* * *}$ & 7.962 \\
\hline INST & $0.007^{* * *}$ & 7.223 & $0.007^{* * *}$ & 6.703 & $0.009^{* * *}$ & 10.878 \\
\hline BIGN & $1.119^{* * *}$ & 29.550 & $1.116^{* * *}$ & 29.568 & $-1.022 * * *$ & 96.184 \\
\hline BOARD & $-0.046^{*}$ & 3.302 & $-0.046^{*}$ & 3.414 & 0.010 & 0.161 \\
\hline BHOLD & $0.006 *$ & 3.035 & $0.006 *$ & 3.019 & 0.003 & 0.887 \\
\hline BPLEDGE & 0.000 & 0.025 & -0.001 & 0.053 & $0.007^{* * *}$ & 7.618 \\
\hline BIND & -0.001 & 0.001 & 0.002 & 0.003 & -0.056 & 1.772 \\
\hline BCONTROL & $0.058^{* *}$ & 4.495 & $0.059 * *$ & 4.669 & -0.009 & 0.104 \\
\hline Intercept & $-14.644^{* * *}$ & 409.759 & $-14.558^{* * *}$ & 409.698 & $3.816^{* * *}$ & 31.571 \\
\hline Industry & \multicolumn{2}{|c|}{ Included } & \multicolumn{2}{|c|}{ Included } & \multicolumn{2}{|c|}{ Included } \\
\hline Year & \multicolumn{2}{|c|}{ Included } & \multicolumn{2}{|c|}{ Included } & \multicolumn{2}{|c|}{ Included } \\
\hline $\mathrm{N}$ & \multicolumn{2}{|c|}{7789} & \multicolumn{2}{|c|}{7789} & \multicolumn{2}{|c|}{7789} \\
\hline Cox \& Snell $R^{2}$ & \multicolumn{2}{|c|}{0.107} & \multicolumn{2}{|c|}{0.107} & \multicolumn{2}{|c|}{0.065} \\
\hline Nagelkerke $\mathrm{R}^{2}$ & \multicolumn{2}{|c|}{0.248} & \multicolumn{2}{|c|}{0.248} & \multicolumn{2}{|c|}{0.155} \\
\hline Sig. & \multicolumn{2}{|c|}{$0.000^{* * *}$} & \multicolumn{2}{|c|}{$0.000^{* * *}$} & \multicolumn{2}{|c|}{$0.000 * * *$} \\
\hline
\end{tabular}

Variable Definitions: MROT1 = an indicating variable of mandatory rotation, which denotes 1 if the company is mandated to rotate any one of its audit partner this year, and 0 otherwise; MROT2 = an indicating variable of mandatory rotation, which denotes 1 if the company is mandated to rotate both of its audit partner this year, and 0 otherwise. All variables definitions are the same as Table 2. ******* Denote significance at the 0.10, 0.05, and 0.01 levels, respectively (two-tailed for all $t$-statistics).

Table 5 contains the results of regressions for exploring the association between mandatory audit partner rotation and companies' choices of successor auditors based on the number of auditors they rotated. Panel A displays the results of companies that rotated only one of their audit partners and Panel B displays the results of companies that rotated both of them.

Panel A shows that the coefficient of MROT1 is significantly positive in Column (1) and is significantly negative in Column (2) which suggests that for companies that rotated only one partner, compared to voluntary rotation companies, mandatory rotation companies are more likely to engage industry specialists to be their successor auditors and less likely to rotate both audit partners and audit firms around audit rotation periods.

Panel B displays the results of companies rotating both of their audit partners. Under the case of rotating both audit partners, it is possible that one of them is rotated by a mandatory rotation and the other is a voluntary rotation; and it is also possible that both audit partners are rotated by mandatory rotations. Therefore, this study further divided these two situations under the case of rotating both audit partners. When only one partner was rotated mandatorily, Column (3) and Column (4) display that, similar to the results of companies rotating only one of their audit partners, the coefficient of MROT1 is significantly positive in Column (3) and is significantly negative in Column (4) which suggests that for companies rotating both of their audit partners; under the situation that only one of the rotated partners is mandatorily rotated, companies are more likely to engage industry specialists to be their successor auditors and less likely to rotate both audit partners and audit firms around audit rotation periods. 
Table 5. Sub-sample logistic regression results of mandatory audit partner rotation and the successor auditor.

\begin{tabular}{|c|c|c|c|c|c|c|c|c|c|c|c|c|}
\hline & \multirow{2}{*}{\multicolumn{4}{|c|}{$\begin{array}{c}\text { Panel A } \\
\text { Rotate Only One Partner }\end{array}$}} & \multicolumn{8}{|c|}{$\begin{array}{c}\text { Panel B } \\
\text { Rotate Both Partners }\end{array}$} \\
\hline & & & & & \multicolumn{4}{|c|}{ One Partner Rotated Mandatorily } & \multicolumn{4}{|c|}{ Mandatory Rotate Both Partners } \\
\hline & \multicolumn{2}{|c|}{$\begin{array}{c}\text { (1) } \\
\text { SUCSPE }\end{array}$} & \multicolumn{2}{|c|}{$\begin{array}{c}(2) \\
\text { CHANGEFIRM }\end{array}$} & \multicolumn{2}{|c|}{$\begin{array}{c}\text { (3) } \\
\text { SUCSPE }\end{array}$} & \multicolumn{2}{|c|}{$\begin{array}{c}\text { (4) } \\
\text { CHANGEFIRM }\end{array}$} & \multicolumn{2}{|c|}{$\begin{array}{c}\text { (5) } \\
\text { SUCSPE }\end{array}$} & \multicolumn{2}{|c|}{$\begin{array}{c}(6) \\
\text { CHANGEFIRM }\end{array}$} \\
\hline & Coeff. & Wald & Coeff. & Wald & Coeff. & Wald & Coeff. & Wald & Coeff. & Wald & Coeff. & Wald \\
\hline MROT1 & $0.893^{* * *}$ & 8.800 & $-1.310 *$ & 3.001 & $0.541^{* *}$ & 4.084 & $-1.240^{* * *}$ & 47.850 & & & & \\
\hline MROT2 & & & & & & & & & $0.118 *$ & 0.093 & $-1.783^{* * *}$ & 31.479 \\
\hline SIZE & 0.177 & 1.210 & -0.227 & 0.379 & $1.339^{* * *}$ & 44.660 & $-0.890^{* * *}$ & 43.615 & $1.318^{* * *}$ & 43.725 & $-0.914^{* * *}$ & 46.218 \\
\hline LEVERAGE & 0.588 & 0.530 & -0.586 & 0.111 & 0.551 & 0.298 & 0.944 & 2.452 & 0.580 & 0.336 & 1.034 * & 2.952 \\
\hline LOSS & $-0.478^{* *}$ & 4.778 & 0.118 & 0.063 & 0.531 ** & 4.543 & $0.345^{* *}$ & 5.716 & $0.498^{* *}$ & 4.040 & $0.375^{* * *}$ & 6.837 \\
\hline CFO & 0.066 & 0.011 & 0.910 & 0.687 & 0.107 & 0.048 & $-1.295^{* * *}$ & 10.852 & 0.125 & 0.067 & $-1.319^{* * *}$ & 11.559 \\
\hline GROWTH & -0.001 & 0.158 & -0.008 & 1.561 & 0.002 & 0.785 & 0.001 & 0.415 & 0.002 & 0.633 & 0.001 & 0.699 \\
\hline ABSTACC & -0.232 & 0.189 & -1.539 & 0.920 & $1.105^{*}$ & 3.150 & -0.197 & 0.222 & 1.065 * & 2.967 & -0.129 & 0.095 \\
\hline INST & $-0.011^{* *}$ & 6.428 & 0.005 & 0.204 & $0.014^{* *}$ & 6.073 & $0.008^{* *}$ & 5.233 & $0.014^{* *}$ & 6.112 & $0.009^{* *}$ & 6.193 \\
\hline BIGN & -0.004 & 0.000 & $-2.785^{* * *}$ & 49.627 & $1.372^{* * *}$ & 13.043 & $-0.600^{* * *}$ & 16.535 & $1.347^{* * *}$ & 12.680 & $-0.629^{* * *}$ & 18.427 \\
\hline BOARD & -0.023 & 0.307 & -0.184 * & 2.761 & -0.019 & 0.130 & $0.062 *$ & 3.651 & -0.013 & 0.058 & 0.059 * & 3.263 \\
\hline BHOLD & 0.004 & 0.442 & 0.014 & 1.080 & 0.001 & 0.012 & 0.002 & 0.172 & 0.001 & 0.033 & 0.002 & 0.209 \\
\hline BPLEDGE & $0.008^{* *}$ & 4.524 & -0.003 & 0.083 & 0.000 & 0.000 & $0.006 *$ & 3.442 & 0.000 & 0.001 & $0.007^{* *}$ & 4.449 \\
\hline BIND & -0.055 & 0.694 & 0.034 & 0.047 & $-0.179 * *$ & 4.697 & -0.026 & 0.249 & $-0.176^{* *}$ & 4.550 & -0.043 & 0.655 \\
\hline BCONTROL & -0.026 & 0.325 & 0.144 & 1.855 & 0.011 & 0.038 & -0.013 & 0.118 & 0.002 & 0.001 & -0.002 & 0.003 \\
\hline Intercept & $-3.455^{* * *}$ & 9.787 & -17.934 & 0.000 & $-13.345^{* * *}$ & 81.103 & $5.431^{* * *}$ & 36.709 & $-12.993^{* * *}$ & 78.818 & $5.303^{* * *}$ & 35.701 \\
\hline Industry & \multicolumn{2}{|c|}{ Included } & \multicolumn{2}{|c|}{ Included } & \multicolumn{2}{|c|}{ Included } & \multicolumn{2}{|c|}{ Included } & \multicolumn{2}{|c|}{ Included } & \multicolumn{2}{|c|}{ Included } \\
\hline Year & \multicolumn{2}{|c|}{ Included } & \multicolumn{2}{|c|}{ Included } & \multicolumn{2}{|c|}{ Included } & \multicolumn{2}{|c|}{ Included } & \multicolumn{2}{|c|}{ Included } & \multicolumn{2}{|c|}{ Included } \\
\hline $\mathrm{N}$ & \multicolumn{2}{|c|}{6139} & \multicolumn{2}{|c|}{6139} & \multicolumn{2}{|c|}{1650} & \multicolumn{2}{|c|}{1650} & \multicolumn{2}{|c|}{1650} & \multicolumn{2}{|c|}{1650} \\
\hline Cox \& Snell $\mathrm{R}^{2}$ & \multicolumn{2}{|c|}{0.011} & \multicolumn{2}{|c|}{0.025} & & & & & & & & \\
\hline Nagelkerke $\mathrm{R}^{2}$ & & & & & & & & & & & & \\
\hline Sig. & 0.0 & & 0.0 & & 0.00 & & 0.0 & & 0.00 & & 0.0 & \\
\hline
\end{tabular}


However, when both partners were rotated mandatorily, Column (5) and Column (6) display that, while the coefficient of MROT1 is still positive in Column (5) and negative in Column (6), the association became not significant in Column (5); which suggests that the tendency to hire industry specialists as successor auditors was less significant for companies where both audit partners are mandatorily rotated. This study conjectures the results to be caused by the reason that, compared with only one audit partner mandatorily rotated or both auditors rotated voluntarily, it is harder to find apposite auditors when both audit partners are mandated to rotate at the same time. Therefore, the cost-benefit considerations of engaging industry specialist auditors under this situation may be different from others, and companies' consideration of engaging an industry specialist as a successor auditor is affected as a result.

Chin and Chi [41] suggest that because lead audit partners usually guide the work, explain the audit evidence, and finally determine the appropriate audit report, and usually have more audit practical experience than concurring partners, the impacts of lead audit partners and concurring partners may be different.

Table 6 presents the regression results for lead and concurring auditors. Panel A reveals that the coefficient of MANROT is significantly positive in both Column (1) and (2) which suggests that for companies that rotated only one partner, mandatory rotation companies are more likely to engage industry specialists to be their successor auditors no matter the rotated audit partner is the lead or concurring one. On the other hand, Panel B shows that the coefficient of MANROT is significantly positive only in Column (3), which denotes the mandatory rotation of leading audit partners. That is, under the situation of rotated both partners, the higher willingness of choosing an industry specialist to be the successor of companies is significant only when the mandatorily rotated auditors are leading partners. The results demonstrate that, when choosing the successors under mandatory rotation, companies have different considerations for lead and concurring auditors.

\subsection{Additional Tests}

\subsubsection{Type of Predecessor Auditors}

While mandatory rotation companies may raise the intension of engaging industry specialist audit partners for minimizing mandatory rotation-related costs, the selection of industry specialist could also be induced by the auditor choice tendency of companies. To discuss the possible influence of companies' auditor choice behavior, we examine the association between mandatory audit partner rotation and companies' successor audit partner choice for companies with specialist and non-specialist predecessor auditor, respectively.

Panel A of Table 7 shows that, for the full sample, the positive association between mandatory audit rotation and engaging industry specialist successor audit partners is significant only for Column (1), which denotes companies with specialist predecessor audit partners. That is, while companies experiencing mandatory rotation were more likely to engage industry specialists to be their successor as a whole, the tendency is significant only for companies with industry specialist predecessor auditors. 
Table 6. Sub-sample logistic regression results of mandatory rotations for lead and concurring auditors.

\begin{tabular}{|c|c|c|c|c|c|c|c|c|c|c|}
\hline & \multicolumn{4}{|c|}{$\begin{array}{c}\text { Panel A } \\
\text { Rotate Only One Partner }\end{array}$} & \multicolumn{6}{|c|}{$\begin{array}{c}\text { Panel B } \\
\text { Rotate Both Partners }\end{array}$} \\
\hline & \multicolumn{2}{|c|}{ (1) } & \multicolumn{2}{|c|}{ (2) } & \multicolumn{2}{|c|}{ (3) } & \multicolumn{2}{|c|}{ (4) } & \multirow{2}{*}{\multicolumn{2}{|c|}{$\begin{array}{c}\text { (5) } \\
\text { BOTHMROT }\end{array}$}} \\
\hline & \multicolumn{2}{|c|}{ LEAD } & \multicolumn{2}{|c|}{ CONCURRING } & \multicolumn{2}{|c|}{ LEAD } & \multicolumn{2}{|c|}{ CONCURRING } & & \\
\hline & Coeff. & Wald & Coeff. & Wald & Coeff. & Wald & Coeff. & Wald & Coeff. & Wald \\
\hline MANROT & $1.655^{* * *}$ & 34.640 & $0.682 * *$ & 5.241 & $0.503 *$ & 2.718 & 0.007 & 0.000 & 0.118 & 0.093 \\
\hline SIZE & $1.619^{* * *}$ & 62.575 & $1.501^{* * *}$ & 70.671 & $0.948^{* * *}$ & 25.508 & $0.962^{* * *}$ & 24.504 & $1.318^{* * *}$ & 43.725 \\
\hline LEVERAGE & -1.583 & 1.726 & $-1.848 *$ & 2.942 & 0.571 & 0.358 & 0.690 & 0.478 & 0.580 & 0.336 \\
\hline $\mathrm{CFO}$ & 0.641 & 0.631 & 1.327 & 2.306 & 0.251 & 0.185 & 0.282 & 0.223 & 0.125 & 0.067 \\
\hline GROWTH & $0.006^{* *}$ & 4.757 & 0.002 & 0.340 & 0.003 & 2.238 & 0.003 & 1.186 & 0.002 & 0.633 \\
\hline ABSTACC & 0.670 & 1.078 & -0.250 & 0.106 & 0.083 & 0.016 & $1.106^{*}$ & 3.276 & $1.065^{*}$ & 2.967 \\
\hline INST & 0.001 & 0.059 & 0.009 & 2.549 & $0.014^{* *}$ & 5.152 & $0.011^{*}$ & 2.985 & $0.014^{* *}$ & 6.112 \\
\hline BIGN & 0.370 & 0.857 & $3.156^{* * *}$ & 9.436 & $1.031^{* * *}$ & 6.807 & $1.327^{* * *}$ & 7.730 & $1.347^{* * *}$ & 12.680 \\
\hline BOARD & -0.039 & 0.478 & -0.067 & 1.888 & -0.090 & 2.456 & 0.000 & 0.000 & -0.013 & 0.058 \\
\hline BHOLD & 0.002 & 0.071 & 0.005 & 0.528 & -0.002 & 0.039 & -0.003 & 0.151 & 0.001 & 0.033 \\
\hline BPLEDGE & -0.008 & 1.590 & 0.000 & 0.006 & -0.010 & 2.531 & 0.001 & 0.010 & 0.000 & 0.001 \\
\hline BIND & -0.022 & 0.054 & 0.102 & 1.672 & $-0.149^{*}$ & 2.757 & -0.071 & 0.619 & $-0.176^{* *}$ & 4.550 \\
\hline Intercept & $-15.71^{* * *}$ & 97.917 & $-17.69^{* * *}$ & 112.99 & $-10.41^{* * *}$ & 64.269 & $-11.33^{* * *}$ & 71.351 & $-12.99^{* * *}$ & 78.818 \\
\hline Industry & \multicolumn{2}{|c|}{ Included } & \multicolumn{2}{|c|}{ Included } & \multicolumn{2}{|c|}{ Included } & \multicolumn{2}{|c|}{ Included } & \multicolumn{2}{|c|}{ Included } \\
\hline Year & \multicolumn{2}{|c|}{ Included } & \multicolumn{2}{|c|}{ Included } & \multicolumn{2}{|c|}{ Included } & \multicolumn{2}{|c|}{ Included } & \multicolumn{2}{|c|}{ Included } \\
\hline $\mathrm{N}$ & \multicolumn{2}{|c|}{6139} & \multicolumn{2}{|c|}{6139} & \multicolumn{2}{|c|}{1650} & \multicolumn{2}{|c|}{1650} & \multicolumn{2}{|c|}{1650} \\
\hline Cox \& Snell $\mathrm{R}^{2}$ & \multicolumn{2}{|c|}{0.052} & \multicolumn{2}{|c|}{0.084} & \multicolumn{2}{|c|}{0.078} & \multicolumn{2}{|c|}{0.077} & & \\
\hline Nagelkerke $\mathrm{R}^{2}$ & & & & & & & & & & \\
\hline Sig. & & & & & & & & & & \\
\hline
\end{tabular}

All variables definitions are the same as Table $2 .{ }^{*}, * * * * * *$ Denote significance at the $0.10,0.05$, and 0.01 levels, respectively (two-tailed for all $t$-statistics). 
Table 7. Logistic regression results of industry specialist and non-industry specialist former audit partners.

\begin{tabular}{|c|c|c|c|c|c|c|c|c|c|c|c|c|}
\hline & \multicolumn{4}{|c|}{$\begin{array}{c}\text { Panel A } \\
\text { Full Sample }\end{array}$} & \multicolumn{4}{|c|}{$\begin{array}{c}\text { Panel B } \\
\text { Lead Auditors }\end{array}$} & \multicolumn{4}{|c|}{$\begin{array}{c}\text { Panel C } \\
\text { Concurring Auditors }\end{array}$} \\
\hline & \multicolumn{2}{|c|}{$\begin{array}{c}\text { (1) } \\
\text { PRE SPE }\end{array}$} & \multicolumn{2}{|c|}{$\begin{array}{c}\text { (2) } \\
\text { PRE NON-SPE }\end{array}$} & \multicolumn{2}{|c|}{$\begin{array}{c}\text { (3) } \\
\text { PRE SPE }\end{array}$} & \multicolumn{2}{|c|}{$\begin{array}{c}\text { (4) } \\
\text { PRE NON-SPE }\end{array}$} & \multicolumn{2}{|c|}{$\begin{array}{c}\text { (5) } \\
\text { PRE SPE }\end{array}$} & \multicolumn{2}{|c|}{$\begin{array}{c}\text { (6) } \\
\text { PRE NON-SPE }\end{array}$} \\
\hline & Coeff. & Wald & Coeff. & Wald & Coeff. & Wald & Coeff. & Wald & Coeff. & Wald & Coeff. & Wald \\
\hline MANROT & 0.334 * & 3.174 & 0.237 & 0.827 & $0.735^{* * *}$ & 7.332 & $1.001^{* * *}$ & 16.382 & $0.732^{* *}$ & 5.916 & -0.081 & 0.053 \\
\hline SIZE & $1.272^{* * *}$ & 102.746 & $1.051^{* * *}$ & 29.119 & $0.848^{* * *}$ & 21.838 & $1.151^{* * *}$ & 40.135 & $1.433^{* * *}$ & 77.183 & $0.928^{* * *}$ & 27.402 \\
\hline LEVERAGE & -0.472 & 0.389 & 0.331 & 0.130 & -0.575 & 0.255 & 0.717 & 0.677 & -1.337 & 1.671 & -0.470 & 0.240 \\
\hline $\mathrm{CFO}$ & 0.419 & 0.948 & 0.456 & 0.649 & -0.353 & 0.247 & 0.559 & 1.041 & 0.375 & 0.415 & 0.181 & 0.076 \\
\hline GROWTH & 0.001 & 0.103 & $0.007^{* * *}$ & 11.922 & 0.002 & 0.573 & $0.006^{* * *}$ & 8.842 & 0.002 & 0.501 & 0.002 & 0.479 \\
\hline ABSTACC & 0.493 & 1.384 & 0.297 & 0.381 & 0.659 & 1.496 & 0.447 & 0.818 & 0.473 & 0.830 & -0.081 & 0.018 \\
\hline INST & $0.007 *$ & 3.618 & 0.000 & 0.001 & 0.000 & 0.006 & 0.004 & 0.570 & 0.002 & 0.148 & $0.010^{* *}$ & 4.023 \\
\hline BIGN & 0.567 * & 2.867 & $0.730^{* *}$ & 5.379 & -0.588 & 1.845 & $0.602 *$ & 3.746 & 0.413 & 0.741 & $1.074^{* * *}$ & 8.078 \\
\hline BOARD & $-0.064^{*}$ & 3.097 & -0.054 & 1.197 & -0.109 * & 3.599 & -0.010 & 0.046 & -0.035 & 0.561 & -0.036 & 0.565 \\
\hline BHOLD & -0.003 & 0.498 & $0.012 *$ & 3.164 & -0.004 & 0.362 & $0.016^{* *}$ & 6.368 & -0.003 & 0.213 & 0.006 & 1.052 \\
\hline BPLEDGE & 0.003 & 0.497 & -0.005 & 0.706 & 0.005 & 0.795 & -0.001 & 0.043 & 0.000 & 0.009 & 0.002 & 0.129 \\
\hline BIND & -0.061 & 1.174 & -0.059 & 0.581 & -0.019 & 0.056 & $-0.151^{* *}$ & 4.024 & -0.004 & 0.004 & -0.020 & 0.076 \\
\hline Intercept & $-11.62 * * *$ & 130.501 & $-10.86^{* * *}$ & 63.019 & $-6.429 * * *$ & 19.691 & $-13.06^{* * *}$ & 94.505 & $-12.93^{* * *}$ & 89.65 & $-11.67^{* * *}$ & 78.622 \\
\hline Industry & \multicolumn{2}{|c|}{ Included } & \multicolumn{2}{|c|}{ Included } & \multicolumn{2}{|c|}{ Included } & \multicolumn{2}{|c|}{ Included } & \multicolumn{2}{|c|}{ Included } & \multicolumn{2}{|c|}{ Included } \\
\hline Year & \multicolumn{2}{|c|}{ Included } & \multicolumn{2}{|c|}{ Included } & \multicolumn{2}{|c|}{ Included } & \multicolumn{2}{|c|}{ Included } & \multicolumn{2}{|c|}{ Included } & \multicolumn{2}{|c|}{ Included } \\
\hline $\mathrm{N}$ & \multicolumn{2}{|c|}{604} & \multicolumn{2}{|c|}{7185} & \multirow{2}{*}{\multicolumn{2}{|c|}{0.180}} & \multirow{2}{*}{\multicolumn{2}{|c|}{0.023}} & \multirow{2}{*}{\multicolumn{2}{|c|}{0.250}} & \multirow{2}{*}{\multicolumn{2}{|c|}{0.021}} \\
\hline Cox \& Snell $\mathrm{R}^{2}$ & & \multicolumn{2}{|c|}{0.020} & & & & & & & & \\
\hline Nagelkerke $\mathrm{R}^{2}$ & & & & & \multicolumn{2}{|c|}{0.252} & \multicolumn{2}{|c|}{0.124} & & & & \\
\hline Sig. & 0.0 & & 0.0 & & 0.0 & & 0.00 & & 0.0 & & 0.0 & \\
\hline
\end{tabular}

All variables definitions are the same as Table $2 .{ }^{*}, * *, * * *$ Denote significance at the $0.10,0.05$, and 0.01 levels, respectively (two-tailed for all $t$-statistics). 
For the rotation between lead and concurring auditors, Panel B of Table 7 reveals that the positive association between mandatory audit rotation and engaging industry specialist successor audit partners is both significant for Columns (3) and (4), which suggest that, when the mandated rotated auditor is a lead partner, companies will select the industry specialists as their successor auditor whether the predecessor is an industry specialist or a non-specialist one. On the other hand, the results of Columns (6) and (7), which show that the coefficient of MANROT is significant only for Column (6), indicate that, when the mandated rotated auditor is a concurring partner, companies will select the industry specialists as their successor auditor only when the predecessor is an industry specialist.

\subsubsection{Audit Firm Tenue}

Although the audit-client relationship is mainly possessed by audit partners, the relations between companies and audit firms may influence the decision of companies to rotate only audit partners or both audit partners and audit firms. To discuss the issue, we explore the association between mandatory audit partner rotation and companies' audit firm switch decisions for companies with longer and shorter firm tenure, respectively. Table 8 shows that MANROT is significant only for companies with longer audit firm tenure. In other words, the audit-client relationship between companies and audit firms did have impact on companies' audit firm switch decisions when they experience mandatory audit partner rotations.

Table 8. Logistic regression results of long and short firm tenure.

\begin{tabular}{|c|c|c|c|c|}
\hline & \multicolumn{2}{|c|}{$\begin{array}{l}\text { Panel A } \\
\text { Firm Tenure More than } 5 \text { Years }\end{array}$} & \multicolumn{2}{|c|}{$\begin{array}{c}\text { Panel B } \\
\text { Firm Tenure Less than } 5 \text { Years }\end{array}$} \\
\hline & Coeff. & Wald & Coeff. & Wald \\
\hline MANROT & $-0.572 * * *$ & 11.247 & -0.638 & 0.379 \\
\hline SIZE & -0.153 & 1.696 & 1.772 & 1.989 \\
\hline LEVERAGE & 0.157 & 0.090 & -8.030 & 2.017 \\
\hline LOSS & $0.539 * * *$ & 16.553 & 0.497 & 0.232 \\
\hline $\mathrm{CFO}$ & $-1.338^{* * *}$ & 17.826 & -0.336 & 0.004 \\
\hline GROWTH & 0.000 & 0.000 & $-0.073^{* *}$ & 3.957 \\
\hline ABSTACC & $-0.551 *$ & 3.001 & 4.005 & 0.394 \\
\hline INST & 0.000 & 0.002 & 0.002 & 0.003 \\
\hline BIGN & $-0.870 * * *$ & 41.131 & -18.710 & 0.002 \\
\hline BOARD & -0.008 & 0.082 & -0.236 & 1.011 \\
\hline BHOLD & 0.000 & 0.003 & 0.013 & 0.128 \\
\hline BPLEDGE & $0.008^{* *}$ & 6.203 & -0.010 & 0.256 \\
\hline BIND & $-0.295^{* * *}$ & 37.696 & 0.159 & 0.129 \\
\hline BCONTROL & $0.078^{* *}$ & 5.616 & 0.525 * & 3.315 \\
\hline Intercept & $-9.115^{* * *}$ & 49.437 & $-18.704^{* * *}$ & 348.776 \\
\hline Industry & \multicolumn{2}{|c|}{ Included } & \multicolumn{2}{|c|}{ Included } \\
\hline Year & \multicolumn{2}{|c|}{ Included } & \multicolumn{2}{|c|}{ Included } \\
\hline $\mathrm{N}$ & \multicolumn{2}{|c|}{2765} & \multicolumn{2}{|c|}{5024} \\
\hline Cox \& Snell $\mathrm{R}^{2}$ & \multicolumn{2}{|c|}{0.182} & \multicolumn{2}{|c|}{0.031} \\
\hline Nagelkerke $\mathrm{R}^{2}$ & \multicolumn{2}{|c|}{0.284} & \multicolumn{2}{|c|}{0.734} \\
\hline Sig. & \multicolumn{2}{|c|}{$0.000 * * *$} & \multicolumn{2}{|c|}{$0.000^{* * *}$} \\
\hline
\end{tabular}

\subsubsection{Different Rotation Period}

The mandatory audit partner rotation in Taiwan is to conduct a substantive examination for companies that were not rotated for five years since 2004 . However, the length of the continuous audit year was extended to be 7 years from 2009. This study used 5 years and 7 years to determine the mandatory and voluntary rotations for two different periods respectively. To explore the possible impact of different rotation limitations on auditor 
selection, we further divided sample companies based on a 5-year and 7-year mandatory rotation period.

Table 9 shows that the positive association between mandatory rotation and the selection of industry specialist auditors is significant only for the 5-year mandatory rotation period while the negative association between mandatory rotation and the indicator of rotate audit firms at the same time is significant only for the 7-year mandatory rotation period. We attribute these results to the fact that since mandatory rotation was relatively unfamiliar to both company and capital market for the first five-year period, the switching cost was higher for this period, and companies with mandatory rotations had higher willingness to engage industry-specific auditor than voluntary rotations. After 2009, most companies have experienced mandatory rotation at least once, and capital market is more use to it as well; compared with the previous period, the motivation of engaging specialist auditors declined with the diminishing of switching cost. For the rotation of audit firms, the results are consistent with the findings of Table 8, which suggests that the audit-client relationship between companies and audit firms positively impact companies' audit firm switch decisions when they experience mandatory audit partner rotations.

Table 9. Logistic regression results of a 5-year mandatory rotations period and 7-year mandatory rotation period.

\begin{tabular}{|c|c|c|c|c|c|c|c|c|}
\hline \multicolumn{5}{|c|}{$\begin{array}{c}\text { Panel A } \\
\text { 5-Year Mandatory Rotations Period }\end{array}$} & \multicolumn{4}{|c|}{$\begin{array}{c}\text { Panel B } \\
\text { 7-Year Mandatory Rotation Period }\end{array}$} \\
\hline \multicolumn{3}{|c|}{$\begin{array}{l}\text { (1) } \\
\text { SUCSPE }\end{array}$} & \multicolumn{2}{|c|}{$\begin{array}{c}(2) \\
\text { CHANGEFIRM }\end{array}$} & \multicolumn{2}{|c|}{$\begin{array}{l}\text { (3) } \\
\text { SUCSPE }\end{array}$} & \multicolumn{2}{|c|}{$\begin{array}{c}(4) \\
\text { CHANGEFIRM }\end{array}$} \\
\hline & Coeff. & Wald & Coeff. & Wald & Coeff. & Wald & Coeff. & Wald \\
\hline MANROT & $1.106^{* * *}$ & 7.542 & -0.395 & 1.987 & 0.243 & 2.131 & $-0.883^{* * *}$ & 23.496 \\
\hline SIZE & $1.530^{* * *}$ & 121.680 & $-0.735^{* * *}$ & 21.227 & $1.630^{* * *}$ & 135.169 & $-1.009^{* * *}$ & 56.501 \\
\hline LEVERAGE & -0.591 & 0.632 & 1.057 & 2.118 & 0.150 & 0.042 & 0.838 & 1.991 \\
\hline LOSS & -0.013 & 0.005 & $0.720 * * *$ & 17.162 & 0.106 & 0.263 & $0.362 * *$ & 6.536 \\
\hline $\mathrm{CFO}$ & 0.090 & 0.045 & $-1.464^{* * *}$ & 12.880 & 1.041 * & 3.076 & $-1.103^{* * *}$ & 12.428 \\
\hline GROWTH & 0.003 & 2.555 & 0.002 & 0.853 & $0.004 *$ & 3.477 & 0.001 & 0.653 \\
\hline ABSTACC & $0.978^{* *}$ & 6.070 & $-1.295^{* *}$ & 4.821 & 0.598 & 1.569 & $-0.502 *$ & 3.200 \\
\hline INST & $0.010^{* * *}$ & 7.301 & $0.011^{* *}$ & 6.230 & 0.003 & 0.495 & $0.007^{* *}$ & 4.419 \\
\hline BIGN & $1.622 * * *$ & 26.017 & $-0.991 * * *$ & 34.062 & $0.621^{* *}$ & 5.080 & $-1.047^{* * *}$ & 60.122 \\
\hline BOARD & -0.035 & 0.973 & 0.042 & 1.300 & -0.036 & 0.963 & -0.030 & 0.697 \\
\hline BHOLD & 0.008 & 2.584 & 0.001 & 0.032 & 0.006 & 1.495 & 0.005 & 1.344 \\
\hline BPLEDGE & 0.002 & 0.503 & 0.004 & 0.781 & -0.006 & 1.571 & $0.009^{* * *}$ & 8.010 \\
\hline BIND & -0.010 & 0.032 & -0.069 & 1.358 & -0.006 & 0.009 & -0.033 & 0.295 \\
\hline BCONTROL & 0.026 & 0.454 & -0.039 & 0.862 & 0.067 & 2.612 & 0.013 & 0.121 \\
\hline Intercept & $-14.77^{* * *}$ & 205.325 & $2.416^{* *}$ & 5.105 & 0.560 & 1.053 & 0.479 & 0.486 \\
\hline Industry & \multicolumn{2}{|c|}{ Included } & \multicolumn{2}{|c|}{ Included } & \multicolumn{2}{|c|}{ Included } & \multicolumn{2}{|c|}{ Included } \\
\hline Year & \multicolumn{2}{|c|}{ Included } & \multicolumn{2}{|c|}{ Included } & \multicolumn{2}{|c|}{ Included } & \multicolumn{2}{|c|}{ Included } \\
\hline $\mathrm{N}$ & \multicolumn{2}{|c|}{3556} & \multicolumn{2}{|c|}{3556} & \multicolumn{2}{|c|}{4233} & \multicolumn{2}{|c|}{4233} \\
\hline Cox \& Snell $\mathrm{R}^{2}$ & \multicolumn{2}{|c|}{0.121} & \multicolumn{2}{|c|}{0.056} & \multicolumn{2}{|c|}{0.099} & \multicolumn{2}{|c|}{0.079} \\
\hline Nagelkerke $\mathrm{R}^{2}$ & \multicolumn{2}{|c|}{0.263} & \multicolumn{2}{|c|}{0.147} & \multicolumn{2}{|c|}{0.248} & \multicolumn{2}{|c|}{0.177} \\
\hline Sig. & \multicolumn{2}{|c|}{$0.000^{* * *}$} & \multicolumn{2}{|c|}{$0.000^{* * *}$} & \multicolumn{2}{|c|}{$0.000 * * *$} & \multicolumn{2}{|c|}{$0.000^{* * *}$} \\
\hline
\end{tabular}

All variables definitions are the same as Table $2 .{ }^{*}, * * * * *$ Denote significance at the $0.10,0.05$, and 0.01 levels, respectively (two-tailed for all $t$-statistics).

\section{Conclusions and Discussions}

Auditor selection is one of a company's important information disclosure strategies and prior studies have suggested that companies' auditor selections are related to their sustainability-related activities. This study demonstrates the influence of the mandatory auditor rotation mechanism on a company's auditor selection strategy from the perspective of the auditees while most prior studies discussed the impact of such mechanism on auditors. As far as the effect of mandatory rotation is concerned, the auditor's choice that follows the rotation; that is, the consequences of implementing this mechanism, should 
be an important consideration for whether this mechanism is worth continuing to be implemented.

Prior studies have demonstrated that, distinct from voluntary rotations, which may have numerous considerations, the main consideration of mandatory rotation should be to minimize its switching cost. Are companies that experience mandatory audit rotation more likely to hire specialist auditors with specific industry knowledge and reputation to minimize the costs of mandatory rotation? Furthermore, in the case of being required to rotate audit partners, do companies rotate only audit partners, rather than changing both audit partners and the audit firm at the same time, to minimize switching costs?

To explore these problems, we study audit partner rotations of listed companies in Taiwan from 2004 to 2016, and expected that, to minimize switching costs, mandatory rotation companies are more likely to select industry specialist auditors to be their successor auditors, and are less likely to rotate audit partners and audit firms at the same time. The empirical results support our expectations that companies that experience mandatory audit partner rotations are more likely to employ industry specialists as successor audit partners, and are more likely to only rotate audit partners instead of rotating audit partners and audit firms during mandatory audit rotation.

This study makes the following contributions. First of all, in terms of the impacts of the mandatory rotation mechanism, while most prior studies have focused on its impact on the audit quality, this study discusses it from a different perspective through exploring the companies' response to different mechanisms to achieve their disclosure and signaling strategies. In addition, in terms of practice, the governance bodies of countries around the world have failed to conclude whether the mandatory audit rotation should be regulated to the partner level or firm level. The empirical results of this study can also provide a reference for policy-making institutions which suggests that mandatory rotation at the partner level may be more efficient.

Author Contributions: L.-J.H. proposed the idea, established the model and gave significant suggestions to the implications of the results, L.-J.H. and J.C. finished the original and final draft of this paper. J.C. collected data, completed the empirical tests and analyzed the results. All authors have read and agreed to the published version of the manuscript.

Funding: This research received no external funding.

Institutional Review Board Statement: Not applicable.

Informed Consent Statement: Not applicable.

Data Availability Statement: Not applicable.

Conflicts of Interest: The authors declare no conflict of interest.

\section{References}

1. Nie, D.; Panfilova, E.; Samusenkov, V.; Mikhaylov, A. E-Learning Financing Models in Russia for Sustainable Development. Sustainability 2020, 12, 4412. [CrossRef]

2. Yumashev, A.; Ślusarczyk, B.; Kondrashev, S.; Mikhaylov, A. Global Indicators of Sustainable Development: Evaluation of the Influence of the Human Development Index on Consumption and Quality of Energy. Energies 2020, 13, 2768. [CrossRef]

3. Chen, L.; Srinidhi, B.; Tsang, A.; Yu, W. Audited Financial Reporting and Voluntary Disclosure of Corporate Social Responsibility (CSR) Reports. J. Manag. Account. Res. 2016, 28, 53-76. [CrossRef]

4. Sun, W.; Huang, H.; Dao, M.; Young, C. Auditor Selection and Corporate Social Responsibility. J. Bus. Financ. Account. 2017, 44, 1241-1275. [CrossRef]

5. Tanyi, P.; Raghunandan, K.; Barua, A. Audit Report Lags after Voluntary and Involuntary Auditor Changes. Account. Horiz. 2010, 24, 671-688. [CrossRef]

6. Ettredge, M.L.; Li, C.; Scholz, S. Audit Fees and Auditor Dismissals in the Sarbanes-Oxley Era. Account. Horiz. 2007, 21, 371-386. [CrossRef]

7. Sankaraguruswamy, S.; Whisenant, J.S. An Empirical Analysis of Voluntarily Supplied Client-auditor Realignment Reasons. A J. Pract. Theory 2004, 23, 107-121. [CrossRef]

8. Copley, P.A.; Douthett, E.B. The Association between Auditor Choice, Ownership Retained, and Earnings Disclosure by Firms Making Initial Public Offerings. Contemp. Account. Res. 2002, 19, 49-75. [CrossRef] 
9. Carpenter, C.G.; Strawser, R.H. Displacement of Auditors When Clients Go Public. J. Account. 1971, 131, 55-58.

10. Francis, J.R.; Wilson, E.R. Auditor Changes: A Joint Test of Theories Relating to Agency Costs and Auditor Differentiation. Account. Rev. 1988, 63, 663-682.

11. Defond, M.L. The Association between Changes in Client Firm Agency Costs and Auditor Switching. A J. Pract. Theory 1992, 11, 16-31.

12. Beasley, M.S.; Petroni, K.R. Board Independence and Audit-firm Type. A J. Pract. Theory 2001, 20, 97-114. [CrossRef]

13. Abbott, L.J.; Parker, S. Auditor Selection and Audit Committee Characteristics. A J. Pract. Theory 2000, 19, 47-67. [CrossRef]

14. Pittman, J.A.; Fortin, S. Auditor Choice and the Cost of Debt Capital for Newly Public Firms. J. Account. Econ. 2004, 37, 113-136. [CrossRef]

15. Fan, J.P.; Wong, T.J. Do External Auditors Perform a Corporate Governance Role in Emerging Markets? Evidence from East Asia. J. Account. Res. 2005, 43, 35-72. [CrossRef]

16. Hodgdon, C.; Tondkar, R.H.; Adhikari, A.; Harless, D.W. Compliance with International Financial Reporting Standards and Auditor Choice: New Evidence on the Importance of the Statutory Audit. Int. J. Account. 2009, 44, 33-55. [CrossRef]

17. Defond, M.L.; Subramanyam, K.R. Auditor Changes and Discretionary Accruals. J. Account. Econ. 1998, 25, 35-67. [CrossRef]

18. Francis, J.R.; Maydew, E.; Sparks, H.C. The Role of Big 6 Auditors in the Credible Reporting of Accruals. A J. Pract. Theory 1999, 18, 17-34. [CrossRef]

19. Carcello, J.V.; Neal, T.L. Audit Committee Characteristics and Auditor Dismissals Following "New" Going-concern Reports. Account. Rev. 2003, 78, 95-116. [CrossRef]

20. Kim, J.B.; Chung, R.; Firth, M. Auditor Conservatism, Asymmetric Monitoring, and Earnings Management. Contemp. Account. Res. 2003, 20, 323-359. [CrossRef]

21. Chow, C.W.; Rice, S.J. Qualified Audit Opinions and Auditor Switching. Account. Rev. 1982, 57, $326-335$.

22. Teoh, S.H. Auditor Independence, Dismissal Threats, and the Market Reaction to Auditor Switches. J. Account. Res. 1992, 30, 1-23. [CrossRef]

23. Krishnan, J. Audit Switching and Conservatism. Account. Rev. 1994, 69, 200-215.

24. Krishnan, J.; Stephens, R.G. Evidence on Opinion Shopping from Audit Opinion Conservatism. J. Account. Public Policy 1995, 14, 179-201. [CrossRef]

25. Lennox, C. Do Companies Engaged in Opinion Shopping Successfully? Evidence form UK. J. Account. Econ. 2000, $29,321-337$. [CrossRef]

26. Louis, H. Acquirers' Abnormal Returns and the Non-Big 4 Auditor Clientele Effect. J. Account. Econ. 2005, 40, 75-99. [CrossRef]

27. Kwon, S.Y. The Impact of Competition within the Client's Industry on the Auditor Selection Decision. A J. Pract. Theory 1996, 15, 53-69.

28. Nagy, A.L. Mandatory Audit Firm Turnover, Financial Reporting Quality, and Client Bargaining Power: The Case of Arthur Andersen. Account. Horiz. 2005, 19, 51-68. [CrossRef]

29. Scott, W.D.; Gist, W.E. Forced Auditor Change, Industry Specialization and Audit Fees. Manag. Audit. J. 2013, $28,708-734$. [CrossRef]

30. An, J.; Mikhaylov, A.; Lopatin, E.; Moiseev, N.; Richter, U.H.; Varyash, I.; Dooyum, U.D.; Oganov, A.; Bertelsen, R.G. Bioenergy Potential of Russia: Method of Evaluating Costs. Int. J. Energy Econ. Policy 2019, 9, 244-251. [CrossRef]

31. Blouin, J.; Grein, B.M.; Rountree, B.R. An Analysis of Forced Auditor Change: The Case of Former Arthur Andersen Clients. Account. Rev. 2007, 82, 621-650. [CrossRef]

32. Chen, C.J.P.; Su, X.; Wu, X. Forced Audit Firm Change, Continued Partner-client Relationship, and Financial Reporting Quality. A J. Pract. Theory. 2009, 28, 227-246. [CrossRef]

33. Ruhnke, K.; Schmidt, M. Changing the Institutional Framework of Statutory Audit: Internal Stakeholders' Perceptions of the Associated Benefit and Costs. Eur. Account. Rev. 2016, 25, 59-79. [CrossRef]

34. Geiger, M.A.; Raghunandan, K. Auditor Tenure and Audit Reporting Failures. A J. Pract. Theory 2002, 21, 67-78. [CrossRef]

35. American Institute of Certified Public Accountants (AICPA). The Commission on Auditors Responsibilities: Report, Conclusions and Recommendations; American Institute of Certified Public Accountants (AICPA): New York, NY, USA, 1978.

36. Myers, J.N.; Myers, L.A.; Omer, T.C. Exploring the Term of the Auditor-Client Relationship and the Quality of Earnings: A Case for Mandatory Auditor Rotation? Account. Rev. 2003, 78, 779-799. [CrossRef]

37. Palmrose, Z.V. An Analysis of Auditor Litigation and Audit Service Quality. Account. Rev. 1988, 63, 55-73.

38. General Accounting Office (GAO). Public Accounting Firms Required Study on the Potential Effects of Mandatory Audit Firm Rotation; General Accounting Office (GAO): Washington, DC, USA, 2003.

39. Balsam, S.; Krishnan, J.; Yang, J. Auditor Industry Specialization and Earnings Quality. A J. Pract. Theory 2003, 22, 71-97. [CrossRef]

40. Chi, H.Y.; Chin, C.L. Firm versus Partner Measures of Auditor Industry Expertise and Effects on Auditor Quality. A J. Pract. Theory 2011, 30, 201-229. [CrossRef]

41. Chin, C.; Chi, H.Y. Reducing Restatements with Increased Industry Expertise. Contemp. Account. Res. 2009, 26, 729-765. [CrossRef]

42. Dunn, K.A.; Mayhew, B.W. Audit Firm Industry Specialization and Client Disclosure Quality. Rev. Account. Stud. 2004, 9, 35-58. [CrossRef] 
43. Lim, C.Y.; Tan, H.T. Non-audit Service Fees and Audit Quality: The Impact of Auditor Specialization. J. Account. Res. 2008, 46, 199-246. [CrossRef]

44. Wang, K.; Wilkins, M.S. The Impact of Audit Firm Industry Differentiation on IPO Underpricing. Pac. Account. Rev. 2007, 19, 153-164. [CrossRef]

45. Carcello, J.V.; Nagy, A.L. Audit Firm Tenure and Fraudulent Financial Reporting. A J. Pract. Theory 2004, 23, 55-69. [CrossRef]

46. Godfrey, J.M.; Hamilton, J. The Impact of R\&D Intensity on Demand for Specialist Auditor Services. Contemp. Account. Res. 2005, 22, 55-93.

47. Mansi, S.A.; Maxwell, W.F.; Miller, D.P. Does Auditor Quality and Tenure Matter to Investors? Evidence from the Bond Market. J. Account. Res. 2004, 42, 755-793. [CrossRef]

48. Ghosh, A.; Moon, D. Auditor Tenure and Perceptions of Audit Quality. Account. Rev. 2005, 80, 585-612. [CrossRef]

49. Datar, S.; Feltham, G.A.; Hughes, J.S. The Role of Audits and Audit Quality in Valuing New Issues. J. Account. Econ. 1991, 14, 3-49. [CrossRef]

50. Beatty, R.P. The Economic Determinants of Auditor Compensation in the Initial Public Offerings Market. J. Account. Res. 1993, 31, 294-302. [CrossRef]

51. Willenborg, M. Empirical Analysis of the Economic Demand for Auditing in the Initial Public Offerings Market. J. Account. Res. 1999, 37, 225-238. [CrossRef]

52. Wang, K.; Iqbal, Z. Auditor Choice, Retained Ownership, and Earnings Disclosure for IPO Firms: Further Evidence. Int. J. Manag. Financ. 2006, 2, 220-240. [CrossRef]

53. Krishnan, G.V. Does Big 6 Auditor Industry Expertise Constrain Earnings Management? Account. Horiz. 2003, 17, 1-16. [CrossRef]

54. Cenker, W.J.; Nagy, A. Auditor Resignations and Auditor Industry Specialization. Account. Horiz. 2008, 22, 279-295. [CrossRef]

55. Mascarenhas, D.; Cahan, S.F.; Naiker, V. The Effect of Audit Specialists on the Informativeness of Discretionary Accruals. J. Account. Audit. Financ. 2010, 25, 53-84. [CrossRef]

56. Craswell, A.T.; Francis, J.R.; Taylor, S.L. Auditor Brand Name Reputations and Industry Specializations. J. Account. Econ. 1995, 20, 297-322. [CrossRef]

57. Ferguson, A.; Stokes, D. Brand Name Audit Pricing, Industry Specialization and Industry Leadership Premiums Post Big 8 and Big 6 Mergers. Contemp. Account. Res. 2002, 19, 77-110. [CrossRef]

58. Chi, W.; Huang, H.; Liao, Y.; Xie, H. Mandatory Audit Partner Rotation, Audit Quality, and Market Perception: Evidence from Taiwan. Contemp. Account. Res. 2009, 26, 359-391. [CrossRef] 